Кроль В. В., аспірант (Національний університет водного господарства та природокористування, м. Рівне)

\title{
КОНЦЕПТУАЛЬНІ ЗАСАДИ АНАЛІЗУ СОЦІАЛЬНОГО КАПІТАЛУ
}

Проаналізовано концептуальні засади ідентифікації соціального капіталу відповідно до ієрархічних рівнів. Визначено, що основними компонентами соціального капіталу є: структурний, пізнавальний та реляційний. Відповідно за кожною з компонент запропоновано індикатори оцінки соціального капіталу на рівні підприємства. Визначено, що найбільш придатними для вимірювання соціального капіталу є оцінки, зібрані в процесі соціологічного моніторингу. Ключові слова: соціальний капітал, компоненти соціального капіталу, структурний соціальний капітал, пізнавальний соціальний капітал, реляційний соціальний капітал, рівні соціального капіталу.

Постановки проблеми. Здатність національної економіки створювати та ефективно використовувати нематеріальні види капіталу все більшою мірою визначає економічну силу нації, іï добробут і прогрес. Структурні зміни в сучасній економіці розвинутих країн і стали тим підгрунтям, на якому виникли і набули високої популярності концепції нематеріальних форм прояву капіталу, в тому числі і соціального капіталу.

Аналіз останніх досліджень та публікацій. Останніми роками спостерігається значний і зростаючий інтерес до теорії соціального капіталу, про що свідчить його застосування до різних дисциплін та численних предметних областей.

Цей інтерес випливає з привабливості концепції, оскільки об'єднує соціологію та економіку, і поєднує ряд ідей, включаючи громадянську традицію, самоідентифікацію, причетність та соціальну згуртованість.

Існуючі дослідження показали, що ефективне управління соціальним капіталом має значні переваги для цілого ряду економічних та соціологічних процесів. Переваги, що стоять за соціальним капіталом, не $є$ новими, а кореневими в роботі ранніх економічних і соціологічних науковців. До сучасних авторів, які $\epsilon$ основоположниками теорії соціального капіталу, включають П'єра Бурдьє, Джеймса Коулмена та Роберта Патнема. Серед вітчизняних науковців висвітлення теорії соціального капіталу проводили А. Бова, О. Грішнова та інші. Особливий інтерес до дослідження викликає взаємодія соціального 
капіталу та управління економічними результатами підприємства.

Виклад основного матеріалу. Поняття соціального капіталу стало популярним лише відносно нещодавно, проте вперше цей термін був використаний майже століття тому. Спочатку визначення «соціальний капітал» з'явилося в книзі, опублікованій в 1916 році в Сполучених Штатах, де обговорювалися шляхи співпраці сусідів, щоб контролювати школи. Автор Ліді Ханіфан назвав соціальний капітал «тим активом, що відчуває більшість людей у повсякденному житті: а саме доброзичливість, спілкування, співчуття та соціальний зв'язок між особою та сім'єю, які складають соціальну одиницю». Згодом цей термін став популярним з виданням в 2000 році бестселера Роберта Патнема «Гра в кеглі наодинці: занепад соціального капіталу Америки».

Ведуться дискусії щодо доцільності терміну «капітал». Соціальний капітал має низку економічних ознак, серед яких - ресурсність, прибутковість, конвертованість. Проте, на відміну від економічного капіталу, соціальний капітал не вичерпується у процесі його використання, а навпаки - втрачається за його невикористання $[1 ; 20]$.

Соціальний капітал відрізняється від інших форм капіталу тим, що він перебуває в соціальних відносинах. Окрім того, соціальний капітал не може «торгуватися» на відкритому ринку, як інші форми капіталу, замість цього він вкладається в группу. Аналіз наукової літератури надав можливості діти висновку, що соціальний капітал має як схожість, так і несхожість з неокапітальними теоріями і, безумовно, дуже відрізняється від класичної теорії капіталу.

Іншим напрямом дискусій серед науковців щодо теорії соціального капіталу є розбіжності в обговоренні рівнів його прояву, типів та детермінант. Результатом є низка концептуальних підходів, кожен 3 яких намагається спростити складний соціальний світ при збереженні дійсності. Як наслідок, на сьогоднішній день наявна значною мірою «бідна» операціоналізація та концептуалізація теорії соціального капіталу.

Загальними рисами більшості визначень соціального капіталу $\epsilon$ те, що вони зосереджені на соціальних відносинах, які мають продуктивні переваги. Різноманітність визначень, виявлених в літературі, випливає з особливого контексту специфіки соціального капіталу, складності її концептуалізації та практичної реалізації. Відтак, можемо констатувати, що на сьогодні в науковій літературі відсутнє встановлене та загально узгоджене визначення соціального капіталу, отож конкретна детермінанта, прийнята в межах наукового дослідження, залежатиме від його мети та об'єктів. 
Враховуючи наявні спільні та відмінні підходи щодо сутності соціального капіталу, точніше ії можна ідентифікувати, конкретизуючи рівень аналізу:

Таблиця 1

Сутність та форми прояву соціального капіталу за ієрархічними рівнями (складено автором за [3; 5])

\begin{tabular}{|c|c|c|c|}
\hline Рівень & $\begin{array}{c}\text { Індивідуальний } \\
\text { рівень }\end{array}$ & Мезорівень & Макрорівень \\
\hline Сутність & $\begin{array}{c}\text { Нематеріальний } \\
\text { актив, що прояв- } \\
\text { ляється у вигляді } \\
\text { приватного блага } \\
\text { як доступні ресу- } \\
\text { рси, впроваджені } \\
\text { в соціальній стру- } \\
\text { ктурі або соціаль- } \\
\text { них мережах, які } \\
\text { будуть приносити } \\
\text { користь своїм } \\
\text { власникам }\end{array}$ & $\begin{array}{c}\text { Нематеріальний ак- } \\
\text { тив, що проявляєть- } \\
\text { ся у вигляді публіч- } \\
\text { ного блага у формі } \\
\text { активів і ресурсів, } \\
\text { що надаються через } \\
\text { відносини в рамках } \\
\text { соціальної структу- } \\
\text { ри колективу } \\
\text { та/або взаємодії з } \\
\text { зовнішнімм мере- } \\
\text { жами, які можуть } \\
\text { бути використані } \\
\text { колективом } \\
\end{array}$ & $\begin{array}{l}\text { Нематеріаль- } \\
\text { ний актив, } \\
\text { що проявля- } \\
\text { ється у ви- } \\
\text { гляді суспі- } \\
\text { льного блага } \\
\text { у формі суку- } \\
\text { пності норм, } \\
\text { традицій, } \\
\text { цінностей, } \\
\text { довіри та ви- } \\
\text { значає хара- } \\
\text { ктер суспіль- } \\
\text { ної взаємодії }\end{array}$ \\
\hline $\begin{array}{l}\text { Форми } \\
\text { прояву }\end{array}$ & $\begin{array}{c}\text { Родина, друзі, } \\
\text { мережа особис- } \\
\text { тих зв'язків, не- } \\
\text { формальні групи } \\
\text { та об'єднання }\end{array}$ & $\begin{array}{c}\text { Заклади освіти та } \\
\text { професійної підго- } \\
\text { товки, підприємст- } \\
\text { ва, установи, гро- } \\
\text { мадські організації, } \\
\text { політичні партії, } \\
\text { економічні альянси, } \\
\text { асоціації }\end{array}$ & $\begin{array}{c}\text { Суспільство, } \\
\text { соціальні } \\
\text { групи, соціа- } \\
\text { льні інститу- } \\
\text { ти }\end{array}$ \\
\hline
\end{tabular}

В науковому середовищі домінує позиція щодо неможливості проведення вимірювання соціального капіталу з високим ступенем достовірності. Попит на відповідні емпіричні дослідження залишається достатньо високим, проте наразі не існує ідеального інструменту для вимірювання соціального капіталу.

Оцінювання соціального капіталу $€$ дещо проблематичним 3 огляду відсутності безпосередніх індикаторів його дії, проте можливо вивести цей ступінь впливу з його детермінант або проявів. Існують визначальні фактори, які впливають на соціальні взаємодії, а отже, дозволяють визначити соціальний капітал. Їх прояви є результатами соціального капіталу, наприклад на макрорівні такими показниками 
можуть бути більш низькі показники злочинності, зменшення толерантності до корупції, підвищення рівня міжособистісної довіри громадян, прозорість ведення бізнесу тощо.

Важливим моментом у вимірюванні соціального капіталу $є$ те, що інструменти вимірювання повинні бути тісно пов'язані з теоретичним розумінням соціального капіталу.

На думку деяких дослідників, зокрема [1; 4; 5], форми прояву соціального капіталу можна згрупувати на чотири основні категорії:

- мережі, відносини і зв'язки;

- довіра;

- громадянська активність;

- норми та цінності.

Основними компонентами соціального капіталу є:

- структурний;

- пізнавальний (когнітивний);

- реляційний.

Розмежування між структурним, когнітивним та реляційним соціальним капіталом розробили Джанін Нагапіта та Сумантра Гошаль. Воно є найпоширенішою та прийнятною основою для розуміння соціального капіталу. Ці компоненти різняться концептуальними відмінностями, доцільними для проведення аналізу, але на практиці соціальний капітал передбачає складні взаємозв'язки між трьома складовими [6].

Структурний соціальний капітал - це мережа людей, яких індивід знає за участю яких він може залучати такі переваги, як інформацію та допомогу.Як правило, це визначається щільністю, зв'язністю, ієрархією та адекватністю мережі відносин у будь-якому конкретному об'єкті, такому як група, організація чи спільнота. Важливими аспектами структурного соціального капіталу є кількість зв'язків, якими володіє людина.

Структурна компонента соціального капіталу відноситься до властивостей соціальної системи, різних форм суспільної організації, що характеризують суспільство. Це стосунки з мережею, але не якість цих відносин, оскільки якість відносин - це реляційна компонента.

Реляційний соціальний капітал - це копмонента соціального капіталу, яка пов'язана з характеристиками та якостями особистих відносин, таких як довіра, обов'язки, повага та навіть дружба. Ключовими аспектами реляційного соціального капіталу є довіра та надійність, норми та санкції, зобов'язання, очікування та ідентифікація. 
Когнітивний соціальний капітал - це спільні цінності або парадигми, які сприяють спільному розумінню відповідних способів дій. Таким чином, пізнавальний соціальний капітал забезпечує сукупність норм прийнятної поведінки.

Отож, враховуючи узагальнені в цій статті теоретичні основи аналізу соціального капіталу, його комплексну оцінку на рівні підприємства доцільно проводити в розрізі різних типів показників. Найбільш вдалою основою їх вимірювання вбачається соціологічний моніторинг, проведений відповідно до компонент соціального капіталу. Схематично це можна зобразити наступним чином:

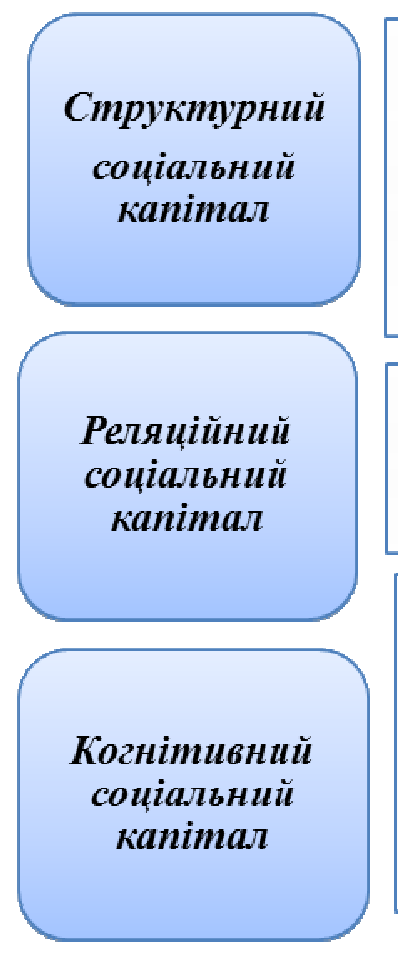

- Структура організаціїта ії ринкове положення (стійкість, конкрентоспроможність);

- Кількість членів організауії;

- Членства та участь у громадському житті;

- Соціальні зв'язки і відносини, кількість або обсяг соціальних ресурсів

- Соціальна взаємодія

- Взаємна відповідальність

-Згуртованість

-Загальна і міжособистісна довіра;

- Спільні цілі;

- Корпоратиена культура;

-Почуттия безиеки;

-Толерантність.

Рисунок. Компоненти та форми прояву соціального капіталу, що можуть покладатись в основу його оцінки

Висновки. В сучасних умовах інформаційної економіки, коли роль нематеріальних ресурсів зростає рік від року, необхідно приділяти пильну увагу розробці методик оцінки соціального капіталу, визначенню та застосуванню конкретних методів, отримання відповідних показників. Обговорення різних методів фінансової оцінки соціального капіталу необхідно, оскільки допомагає зрозуміти, як насправді працює підприємство і його співробітники, які цілі стоять перед підприємством, в якому напрямку воно рухається. Відповідно до за- 
пропонованих компонент соціального капіталу, визначено його форми прояву на рівні підприємства, які можуть в подальшому слугувати індикаторами комплексної оцінки.

1. Бурдьє П. Форми капіталу (1986). Культурна теорія: антологія. 2011. С. 8193. URL: www.ecsoc. msses.ru. (дата звернення: 15.11.2018). 2. Грішнова 0., Полив'яна Н. Соціальний капітал: сутність, значення, взаємозв'язок з іншими формами капіталу. Україна: аспекти праці. 2009. С. 19-24. URL: http://nbuv.gov.ua/UJRN/Uap_2009_3_6 (дата звернення: 15.11.2018). 3. Грішнова О. А. Людський, інтелектуальний і соціальний капітал України: сутність, взаємозв'язок, оцінка, напрями розвитку. Соціально-трудові відносини: теорія та практика. 2014. № 1. С. 34. URL: http://nbuv.gov.ua/UJRN/stvttp_2014_1_5 (дата звернення: 15.11.2018). 4. Коулман Д. Соціальний капітал у створенні людського капіталу. Американський журнал соціологіï. 1988(94). С. 95-120. 5. Claridge Т. Соціальний капітал та управління природними ресурсами : неопублікована дисертація. Університет Квінсленд, Брісбен, Австралія. 2004. 6. Nahapiet J., Ghoshal S. Соціальний капітал, інтелектуальний капітал та організаційні переваги. Знання та соціальний капітал. 2000. С. 119-157.

\section{REFERENCES:}

1. Burdie P. Formy kapitalu (1986). Kulturna teoriia: antolohiia. 2011. S. 81-93. URL: www.ecsoc. msses.ru. (data zvernennia: 15.11.2018). 2. Hrishnova 0., Polyviana N. Sotsialnyi kapital: sutnist, znachennia, vzaiemozviazok z inshymy formamy kapitalu. Ukraina: aspekty pratsi. 2009. S. 19-24. URL: http://nbuv.gov.ua/UJRN/Uap_2009_3_6 (data zvernennia: 15.11.2018). 3. Hrishnova O. A. Liudskyi, intelektualnyi i sotsialnyi kapital Ukrainy: sutnist, vzaiemozviazok, otsinka, napriamy rozvytku. Sotsialno-trudovi vidnosyny: teoriia ta praktyka. 2014. № 1. S. 34. URL: http://nbuv.gov.ua/UJRN/stvttp_2014_1_5 (data zvernennia: 15.11.2018). 4. Koulman D. Sotsialnyi kapital u stvorenni liudskoho kapitalu. Amerykanskyi zhurnal sotsiolohii. 1988(94). S. 95-120. 5. Claridge T. Sotsialnyi kapital ta upravlinnia pryrodnymy resursamy : neopublikovana dysertatsiia. Universytet Kvinslend, Brisben, Avstraliia. 2004. 6. Nahapiet J., Ghoshal S. Sotsialnyi kapital, intelektualnyi kapital ta orhanizatsiini perevahy. Znannia ta sotsialnyi kapital. 2000. S. 119-157.

Рецензент: д.е.н., проф. Міщук Г. Ю. (НУВГП). 
Krol V. V., Post-graduate Student (National University of Water and Environmental Engineering, Rivne)

\section{CONCEPTUAL FOUNDATIONS OF SOCIAL CAPITAL ANALYSIS}

The conceptual basics of social capital identification according to its hierarchical levels are analysed. It is determined, that the main components of social capital are structural, relational and cognitive capital. Based on the understanding of social capital in complex of specific forms (networks, relationships and relationships; trust; civic activity; norms and values), an approach to the identification of its components on different hierarchical levels of economic relations is developed. According to each of the components indicators of social capital evaluation at the enterprise level are proposed. It is grounded, that the most suitable for measuring social capital are esteems picked in the sociological monitoring.

Keywords: social capital, components of social capital, structural social capital, cognitive social capital, relational social capital, levels of social capital.

Кроль В. В., аспирант (Национальный университет водного хозяйства и природопользования, г. Ровно)

КОНЦЕПТУАЛЬНЫЕ ОСНОВЫ АНАЛИЗА СОЦИАЛЬНОГО КАПИТАЛА

Проанализированы концептуальные основы идентификации социального капитала в соответствии с иерархическими уровнями. Определено, что основными компонентами социального капитала являются: структурный, познавательный и реляционный. За каждой из компонент предложено индикаторы оценки социального капитала на уровне предприятия. Определено, что наиболее пригодными для измерения социального капитала являются оценки, собранные в процессе социологического мониторинга.

Ключевые слова: социальный капитал, компоненты социального капитала, структурный социальный капитал, познавательный социальный капитал, реляционный социальный капитал, уровни социального капитала. 